\title{
The Impact of Foreign Direct Investment on the Nigerian Banking Sector
}

\author{
${ }^{1}$ Korna, Johnmark M., ${ }^{2}$ Ajekwe, Tagher,${ }^{3}$ Idyu, Isaac A. \\ ${ }^{1}$ Research Fellow, Banking and Finance Department, University of Nigeria Nsukka, Nigeria. \\ ${ }^{2}$ Assistant Lecturer,Accounting and Finance Department, University of Agriculture Makurdi, Benue State, \\ Nigeria. \\ ${ }^{3}$ Research Fellow, Banking and Finance Department, University of Nigeria Nsukka, Nigeria.
}

\begin{abstract}
This work studies the level of impact; foreign direct investment has on the Nigerian banking sector in the wake of the unprecedented capital flight from the Nigerian economy during the recent global economic recession (the credit crunch). Data which are secondary data nature were obtained from statistical bulletins of the Central Bank of Nigeria. The expost-facto research design was adopted to determine the level of the impact for 25 deposit money banks for the period 2006-2010. The ordinary least square (OLS) estimation technique was employed using statistical packaging for social sciences (SPSS) computer software version 16.0 for statistical analysis. Results revealed that there is a non-positive significant impact of foreign direct investment on the equity capital of the Nigerian banking sector, there is a negative insignificant impact of foreign direct investment on the liquidity position of the Nigerian banking sector and there is a negative insignificant impact of foreign direct investment on the total assets of the Nigerian banking sector. It is recommended therefore that the Nigerian Government should take more seriously the responsibility of creating an enabling environment for effective, value- adding foreign direct investment in the banking sector without losing the prerogative of sovereignty. It is also recommended that already existing foreign direct investment in Nigeria should be sustained and that Government should begin to look at foreign direct investment from a deeper perspective. The quality and structure of foreign direct investment should now be viewed from the perspective of investment in broader aspects of the economy (i.e power, manufacturing, banking, and export-oriented industries) and the use of local suppliers, rather than a lopsided focus on extractive industries.
\end{abstract}

\subsection{Background To The Study}

\section{Introduction}

Foreign direct investment is viewed as a major stimulus to economic growth in developing countries. Its ability to deal with two major obstacles, namely, shortages of financial resources and technology and skills, has made it the centre of attention for policy-makers in low-income countries in particular. Only a few of these countries have been successful in attracting significant FDI flows however. From the early 1970's net resource flows to developing countries have followed an uneven path, but have risen rapidly since 1986 to an unprecedented U.S \$285 billion in 1996(World Bank,1996). The fluctuating nature of private capital flows has played a key role in this. Whereas official flows have continued broadly unchanged after a peak in 1989-91 private capital flows have experienced two waves of explosive growth, the first from 1975 to 1981, dominated by bank lending involving a high proportion of recycled petrol-dollars, the second since 1990,dominated by foreign direct investment.

In the 1970s FDI made up only 12\% of all financial flows to developing countries (World Bank, 1996). Between 1981 and 1984 there was a sharp fall in private lending as international banks lost confidence in borrowing countries financial stability following the debt crisis of 1982. Since the mid 1980's the growing integration of markets and financial institutions, increased economic liberalization, and rapid innovation in financial instruments and technologies, especially in terms of computing and telecommunications have contributed to a near doubling of private flows. Most significant has been the steady progression of FDI to a $35 \%$ share in 1990-1996(World Bank, 1996). An examination of net private capital flows by income group reveals the fluctuating nature of those to middle-income countries which were severely affected by the debt crisis of 1982 and to a lesser extent by the 1994 Mexican crisis. Low income countries, on the other hand have seen a smoother rise in inflows of private capital. Most of them were less affected by the debt crisis, because of their low level of commercial bank loans, due, in part, to their previously closed economies and their lack of suitable financial markets. It was only towards the end of the 1970s that those in Asia in particular began to open their doors wider for foreign capital.

According to the World Bank, Nigeria is the second largest foreign direct investment recipient in Africa (World Bank, 1996). Traditionally FDI had been concentrated in the extractive industries, but there has been a recent diversification into the manufacturing, services (banking sector) and other sectors respectively. 
The regulatory frame-work for the promotion of foreign direct investment received a boost in Nigeria with the enactment of the Nigerian Investment Promotion Commission Act and the Foreign Exchange (Monitoring and Miscellaneous Provisions) Act all in 1995. A look at the trend of FDI in Nigeria since 1961 has shown that the economy has lagged in FDI inflows. Sectoral composition of FDI inflows into Nigeria lacks production oriented investment that could help integrate the economy into international production chains. On the aggregate, at $\$ 10371.5$ and $\$ 2555$.9million the naira equivalent of FDI inflows and outflows respectively was the highest for 40years. It is equally interesting to know that the overvaluation of naira equally accounted for the seemingly heaviest net inflows of FDI into Nigeria in 1982 when the exchange rate was U.S\$1.49 to $\$ 1$ and the consequent FDI activities resulted in $\$ 2,414.8$ million. That is, with only $\$ 1,624.9$ million, the recorded net flow in dollar terms was $\$ 2,414.8$ million. The huge net inflow was due to substantial unmerited profit from United Kingdom (UK) companies operating in Nigeria as well as due to other foreign liabilities which TNC's affiliates operating in Nigeria from UK and USA were to pay as overseas commitments, but inadequate foreign exchange made such accrued payment impossible. A further analysis of the flows revealed that for two consecutive years (i.e. 1989 and 1990 activities of foreign investors, on the whole, resulted in Nigeria becoming a net exporter of capital resources (i.e. making more outflows than inflows) to the tune of $\$ 59.4$ and $\$ 57.8$ million respectively. Regional analysis of the flows has shown that American foreign investors were the most inconsistent in Nigerian economy. During the 40 years, they recorded 15 years of net outflow of net capital flows beginning from 1975. Both UK and Western European foreign investors recorded 4 years of net outflow of FDI each. Investors from other unspecified countries appeared most consistent as their inflow of capital always exceeded their outflows (except for three years i.e. civil war year of 1967, 1985 and the 1993).

The unprecedented explosion in the Nigerian banking industry during the late 1980s attested to how the performance of the operators in a sector can attract foreign investors. The launch of the Structural Adjustment Programme (SAP) in July 1986 opened the flood gate of applications for banking licenses both by foreign and domestic investors. There was a phenomenal increase in the number of registered banks in operation due to perceived high level of illegal arbitrage profits made from trading in foreign exchange. Between 1985 and 1992, for instance, the number of licensed commercial and merchant banks in the country increased from 40 to 120 (Uche/Osho, 1997). There was therefore massive influx of foreign investors into the banking sector during this period. The Nigerian banking sector propelled by the 2005 consolidation, is today steadily positioning itself as the key driver for the Nigerian economy. Though the challenges brought about by the global economic recession have created a lot of setback for the sector, it has remained consistent in growth. Recently, the financial times described it as the fastest growing sector of the Nigerian economy. Operating at the short term end, the sector was rated by Fitch Corporate (Fitch) as recording the highest credit growth among countries covered by Fitch during 2007/2008. For the banking sector to fully maximize its potential of driving Nigeria's economic resurgence, and ultimately becoming a regional financial centre, experts say that there necessarily has to be an infusion of foreign players and capital from across borders. The entrance of foreign investors will benefit the country by providing deeper liquidity to the market with the resultant reduction in the cost of capital. This would in turn impact on production, employment and living standards. Given the competition amongst countries for foreign direct investment, Nigeria (especially the Nigerian banking sector) has the challenge of persuading astute investors to impact capital in Nigeria. The recent global economic meltdown has however raised a lot of concern to economic analysts and development experts. Following the unprecedented level of capital flight that occurred during the last credit crunch, the challenge is whether foreign direct investment is a worth while activity at all.

\subsection{Statement Of The Problem}

In spite of the laudable benefits the Nigerian banking sector stands to derive from the inflow of foreign capital (FDI) and its attending contribution to economic growth, improvement of the living standard of the people and the provision of social amenities, the problem arises as to what extent the Nigerian banking sector and indeed the entire economy should depend on foreign direct investment.

The credit crunch which dealt a total blow to banks in the United States (US), Europe and Asia also came to roost in Nigeria. It is no longer a secret today that the Nigerian financial system most particularly the banking sector, is experiencing a liquidity crisis which has made banks to mop up any available funds to fortify themselves and avoid lending to one another. The phenomenon is believed by analyst to be a back lash from the severe credit crunch that plagued international financial institutions. In recent years, hedge funds and private equity firms from Asia, the US and Europe invested heavily in equities and bond markets in Nigeria. But as institutional investors around the world battled to provide cushion for their credit markets which was thrown into unprecedented deficit as a result of the credit crunch, they had to pull out their funds from Nigeria. From 2006 and 2007, foreign direct investment (FDI) in Nigeria stood at $\$ 26.5$ billion according to estimates of the United Nations Conference on Trade and Development. In 2007 alone, the front line banks were said to have raised more than $\$ 10$ billion in capital to increase their capacity to lend (Salif, 2008). The bulk of these funds 
have been withdrawn by their owners. Financial analyst say the implication of this capital flight is that the economy may take a much longer time to recover because the FDI's will not return immediately even when the dust might have settled. A similar scenario played itself out with the indigenization policy of the 1980's when foreign investors were driven away and it took a long time to bring some of them back.

Worried by the level of unprecedented capital flight that occurred during the last credit crunch, the researcher in this work examined and studied the extent to which foreign direct investment (FDI) could impact on or affect an economy. The challenge of most developing economies today (Nigeria inclusive) is their overdependence on foreign capital which do not bring positive impacts only but negative impacts as well. This work has therefore, tried to look at the extent to which such impact is; or should be, on the Nigerian banking sector, with a view to proffering possible recommendations.

\subsection{Research Questions}

Our research questions are:

(1) What level of impact does foreign direct investment have on thecapital base of the Nigerian banking sector?

(2) What impact does foreign direct investment have on liquidity position of Nigerian banks?

(3) What is the impact of foreign direct investment on the total asset size of the Nigerian banking sector.

\subsection{Research Objectives}

The objectives of the study are as follows:

(1) To ascertain the total amount of cumulative FDI capital inflow that has come into the Nigerian banking sector from the year 2006 to 2010.

(2) To ascertain the level of impact foreign direct investment has on the liquidity position of the Nigerian banking sector.

(3) To determine the level of impact foreign direct investment has on total asset size of the Nigerian banking sector.

\subsection{Hypotheses Of The Study}

The hypotheses of our study are:

(1) $\mathbf{H}_{\mathbf{0}}$ Foreign direct investment does not have a significant positive impact on the capital base of the Nigerian banking sector.

(2) $\mathbf{H}_{\mathbf{0}}$ Foreign direct investment does not have a significant positive impact on liquidity position of the Nigerian banking sector.

(3) $\mathbf{H}_{\mathbf{0}}$ Foreign direct investment does not have a significant positive impact on total asset size of the Nigerian banking sector.

\subsection{Scope Of The Study}

The emphasis of this study is on twenty five (25) deposit money banks. The period 2006-2010 covers the aspect dealing with our data for statistical analysis. The time period has been selected considering that it offers recent time series observations and it constitutes a period of structural changes for the Nigerian banking sector.

\subsection{Key Words}

Foreign capital: This means convertible currency, plant, equipment, spare parts, machinery, raw materials and other business assets, other than goodwill that is brought into Nigeria with no initial disbursement of Nigerian foreign exchange and is intended for the production of goods and services related to an enterprise.

Negative list: This includes those sectors of investment prohibited to both foreign and Nigerian investors such as production of arms, ammunition, narcotic drugs and psychotropic substances etc.

Portfolio investment: This is an investment in shares or other securities traded on the Nigeria stock exchange.

Transfer price: This is the book keeping price at which a good or service is sold by one unit or company within a firm or group to another.

Authorized dealer: These are local banks or any other financial institutions licensed to deal in foreign exchange in Nigeria.

Imputed service charge: This is the excess of property income received on loans deposits held, over the interest paid out to the depositors. 


\subsection{Theoretical Review}

\section{Literature Review}

\subsection{Introduction}

Growth, in neoclassical theory, is brought about by increase in the quantum of factors of production and in the efficiency of their allocation. In a simple world of two factors, Labor but capital, it is often presumed that low-income countries have abundant labor but scarce capital. This situation arises owing to shortage of domestic savings in these countries, which places constraint on capital formation and hence growth. Even where domestic input in addition, to labor, is readily available and hence no problem of inputs supply, increased production processes in low-income countries are based. International capital flows (ICFs) readily become an important means of helping developing countries to overcome their capital shortage problem. One of the components of international capital flows is foreign direct investment (FDI).Other components are:

(1)Official flows from bilateral sources (e.g. developed and OPEC countries) and multilateral sources (such as the World Bank and its two affiliates: the International Development Association-IDA, and the InternationalFinance-Corporation-IFC, concessional and non-concessional terms.

(2)Commercial Bank Loans (including export credits.)

Economic theory suggests that capital will move from countries where it is abundant to counties where it is scarce. This pattern of movement will be informed by the returns on new investment opportunities, which are considered higher where capital is limited. The resultant capital relocation will boost investment in the recipient country and, as Summers (2000) suggests, bring enormous social benefits. Underlying this theory is the premise that returns to capital decrease as more machinery is installed and new structures are built, although, in practice, this is not always, or even generally true.

Although economic theory and empirical investigations have much to say about where FDI may flow, both the theory and the evidence are less definitive about the impact of such flows like trade. FDI is regarded as a two-way flow, with most of the major providers also being the major recipient. FDI is supposed, at least theoretically, to be a positive-sum game (Julius, 1991). For Example, Mishra et al. (2001) revealed that whereas FDI has been associated with higher growth in some countries, it has also been associated with a higher incidence of crises. This striking revelation poses a lot of challenges to how much is known already of FDI. One of these challenges is an urgent need to revisit the conceptual and theoretical underpinnings upon which foreign direct investment is based. Revisit of the conceptual and theoretical foundations of FDI according to Oyeranti, O.A (2003) would bring to the fore relevant issues embedded in economic growth/developmental objectives of developing economies like Nigeria and foreign direct investment.

\subsection{Fdi: Meaning And Rationale}

Foreign direct investment (FDI) is a major component of international capital flows. According to Thirlwall (1994), FDI refers to investment by multinational companies with headquarters in developed countries. This investment involves not only a transfer of funds (including the reinvestment of profits) but also a whole package of physical capital, techniques of production, managerial and marketing expertise, products advertising and business practices for the maximization of global profits.

From the point of view of Development Assistance Committee (DAC) of the Organization for Economic Co-operation and Development (OECD), FDI is conceptualized as net financing by an entity in a developed country, which has the objective of obtaining or retaining a lasting interest in an entity resident in a developing country. The notion of lasting interest connotes a long-term relationship where the direct investor has a significant influence on the management of the enterprise, reflected by ownership of at least 10 percent of the shares of the enterprises, or equivalent in voting power or other means of control.

It is common in the literature to observe that foreign direct investment (FDI) and foreign private investment (FPI) are used interchangeably. This perhaps explains why the International Monetary Fund's Balance of Payments Manual defines foreign direct investment as investment made to acquire a lasting interest in a foreign enterprise with the purpose of having an effective voice in its management. Another institution, the World Trade Organization (1996) also observes that FDI occurs when an investor based in one country (the home country) acquires an asset in another country (the host country) with the intent to manage that asset. All the conceptualizations given above in respect of FDI or FPI are the same, though little differences as we shall soon see exist however. They all suggest that the management dimension is what distinguishes FDI from portfolio investment in foreign stocks, bond and other financial instruments. FDI therefore, should be seen as the sum of the following components:

(a) New equity from the foreign company in the home country to the company in the host country.

(b) Reinvested profits earned from the company and

(c) Long-and short -term net loan from the foreign to the host company.

The other component of international capital flow is portfolio capital flows (PCF). It is a concept of cross-border capital flows that seems to have no precise meaning. According to a survey of PCF definition, 
Wilkins (1999) advised that (PCF) should be seen as applying to 'only long-term investments other than FDI. Conceptualization problem of (PCF) notwithstanding, it is conventionally referred to as total private capital flows (Odedokun, 2003).

FDI is a two-way flow. The rationale for FDI must equally be two-dimensional recognizing the fact that two sets of interest are involved in FDI: interest of the foreign investor, and that of the host country. The World Bank (1997) observed that both domestic and international structural forces were driving direct investment to developing countries since the early 1990s. In industrial countries, the primary forces revolved around the search for higher returns, and opportunities for risk diversification. While looking out for higher returns as well as avenues to diversify their risk at home, two other key developments in industrial countries reinforce the desire of foreign investors to look outwardly. First competition and rising cost in domestic markets, along with falling transport and communication cost encourage foreign firms to look opportunities to increase efficiently and returns (that is profits) by producing abroad. This has led to progressive globalization of production and to the growth 'efficiency-seeking FDI flows. Second, the transformation of financial markets from relatively insulated and regulated national markets to a more globally integrated market. This happens as a result of a mutually reinforcing process of advances in communications, information, and financial markets.

In developing countries, enabling environment for FDI has equally developed. Since the mid-1980s, a lot of countries have embarked on structural reform programs leading to increased openness of their economies. Examples of these reforms include: the progressive lowering of barriers to trade and foreign investment; the liberalization of domestic financial markets and removal of restrictions on capital movements and the implementation of privatization programs, thus strengthening the relevance of private sector in economic growth and development process in developing economies.

\subsection{Differences Between Direct And Portfolio Investment}

As we have discussed above, there are two broad species of foreign investments; these are portfolio investment and direct investment. Direct foreign investment occur when foreigners either wholly or jointly with local investors establish physical presence in another country through acquisition of physical assets such as factories, buildings, plants and machinery etc. In other words, the foreign entity usually establishes a branch operational base or by establishing subsidiary relationships. These developments have given rise to the concept of the multinational enterprise. By definition, a multinational enterprise is one with investment and sales in two or more countries. Example of multinational companies include: IBM, Microsoft, Pfizer, shell petroleum etc.

The following differences exist between direct and portfolio investment:

(i) In a direct foreign investment the investor establishes physical presence in the country. Under portfolio investment, the investor need not establish physical presence.

(ii) In a direct investment, the foreign investor is directly involved in the control and management of the enterprise. In the case of portfolio investment, the investor has no intention of participating in the management of the enterprise.

(iii) Direct investment is long-term in nature. In a portfolio investment, the investor is usually interested in immediate or short-term financial gain. Such funds will remain in an economy only if the returns are consistent with expectations, or at least at a tolerable level, otherwise, the funds move.

(iv) In some countries, different laws may regulate the two types of investments. For instance, in Nigeria, the law guiding direct foreign investment is the Nigeria investment promotion council Act 1995, while foreign portfolio investment is largely regulated by the foreign exchange (monitoring and miscellaneous provisions) Act 1995.

(v) It is more expensive to embark on foreign direct investment than in foreign portfolio investment.

(vi) With the exceptions of venture capital which usually starts as foreign direct investment and terminates as foreign portfolio investment, the distinction between FDI and FPI is fairly perceptible from the characteristics of the investment and the investors.

(vii) The economic effects of divestment (withdrawal) of FPI are more disrupting to the economy of the host country than divestment of FDI. The case of the East Asian countries is a case in point. Analysts tend to agree that the East Asian crisis was triggered internally, by macro-economic instability and aggregated externally, by sudden withdrawal of foreign capital from the economies.

(iii) In terms of real values of a nation's social and economic development, FDI ranks ahead of FPI.

\subsection{The Origin/Concept Of Banking}

Banking started as far back as the $13^{\text {th }}$ century when a group of Italian goldsmiths migrated from an Italian province called Lombardy to settle in a part of London, today known as Lombard Street in London. By gradual process, these goldsmiths before the seventeenth century had evolved a system of transactions which today is said to have given birth to our present day banking system after a series of revolutions and innovations. 
In the days before the London goldsmiths began accepting deposits of coins and valuables, city merchants and other wealthy people kept such items at the royal mint, which at that time was situated in Tower of London in 1640.King Charles 1 needed money to pay for his army and, unable to persuade parliament to vote him the cash he wanted, he seized $\$ 200,000$ of bullion belonging to the Merchants. This of course, meant that the mint could no longer be used as a public safe deposit so that the merchants began to search for other places where they could keep their valuables. The goldsmiths, because of their trade, had excellent strong rooms, so they became an obvious choice. As an acknowledgement for deposits the goldsmiths issued receipts which were being passed from one trader to another for settlement of debts. This saved a trader with a debt a pay from having to go to his goldsmith, present the receipt, draw out the coins required and then hand them over to his creditor, who would immediately deposit them with his own goldsmith. It was much simpler just to transfer the receipt. To help in this, the goldsmiths began to issue receipts in convenient denominations and to make them payable to bearer so that the title to the receipt would pass by delivery. This was where we got the idea of making bank notes payable to bearer. The goldsmiths began to concentrate on the banking side of their business and soon found that, at any one time, only a small proportion of the coins they were holding for safe-keeping would be required to meet demands for repayments of their receipts. They began to lend the surplus monies and charge interest for doing so. Other services were developed such as deposit accounts, discounting (or cashing) bills of exchange before the date for payment, and dealing in bullion and foreign currencies.

\subsection{Empirical Review}

\subsection{Guidelines For Direct Foreign Investment In Nigeria}

As mentioned previously, the Nigeria Investment Promotion Council (NIPC) Act 1995 deals with FDI while the Foreign Exchange Act 1995 is the primary legislation on FPI. The relevance of the NIPC Act or foreign portfolio investment is that through it, there are no more restrictions on the percentage of equity participation by foreigners in Nigerian companies. In other words, foreigners are free to invest in any enterprise of their choice, subject to two sectoral exceptions, namely "negative list" and "petroleum enterprises". The restrictions with respect to petroleum enterprises were removed by NIPC (Amended) Act 1998. The negative list is contained in section 32 of the investments prohibited to all investors (foreign and Nigerian). The list comprises:

(i) Production of arms, Ammunitions etc.

(ii)Production of and dealing in narcotic drugs and psychotropic substances.

(iii)Production of military and paramilitary wears including those of the police, customs, immigration and prison service.

(iv)Such other items as the federal government may from time to time determine.

The implication is that, apart from the negative list, foreign investors may invest in any enterprise in Nigeria

\subsection{Banking In Nigeria And The Sectoral Distribution Of Fdi}

The idea of banking in Nigeria dates back to the early period of the colonial administration. The British traders had monopolized all commercial and economic activities in Nigeria having introduced the use of the British silver coins as a medium of exchange and means of payments. The activities of the expatriate (mainly British) corporations, the financial transactions of the colonial government, the decline of the barter system of exchange, and the increasing acceptance of the British silver currency pressurized the need for modern day banking in Nigeria principally for the proper execution and transmission of funds, to effectively and efficiently serve the British colonial government and their corporations.

According to Uche (2005), the participation of foreign investors in the Nigerian banking arena at least in the broad sense dates back to the origin of banking in the country. Commercial banking for instance, commenced in 1891 with the establishment of the African Banking Corporation. The moving force behind the establishment of the $\mathrm{ABC}$ was George William Nevile. With the support of the chairman of his company sir Alfred Lewis Jones, he convinced the ABC, a South African bank to open an office in Lagos. In 1894 the bank metamorphosed into the Bank of British West Africa (BBWA). In 1899, a second foreign bank- The Bank of Nigeria- was established. In 1916, the Colonial Bank established its presence in Nigeria. Barclays Bank entered the Nigerian banking arena in 1925 through the merger between the Colonial Bank, the Anglo-Egyptian Bank and the National Bank of South Africa. In 1948, the British and French Bank for Commerce and Industry was established (later to become the United Bank for Africa). Essentially, these foreign banks were established with the objective of providing services for the British commercial enterprises. The first indigenous bank- the Industrial and Commercial Bank- was established in 1929 (Uche, C.U, 2005). The Nigerian banking sector today consist of the Central Bank of Nigeria (CBN), money deposit banks, development banks, micro finance banks and other institutions. Owning to its crisis in the past; the Nigerian banking sector has not actually done well in attracting FDI. However with the recent consolidation exercise, the banking sector is now attracting heavy attention from foreign investors. For example \$500million was brought into the sector through FDI in 2005 after 
the consolidation exercise. Cumulative FDI in Nigeria has been generally low. Total FDI increased systematically between 1970 and 1984 when it peaked at about \$8.4billion. Thereafter, it declined systematically to reach about \$1billion in 1992 after which it resumed a rising trend. The indication is that Nigeria has not been able to continuously attract FDI. Indeed between 1985 and 1992, foreign investors really relocated away from Nigeria. With respect to the sectoral distribution of FDI, it can be seem that the pattern does not depict that of a country that is really developing. For example, contrary to expectations at initial stages of development, services sector (banking sector inclusive) tended to dominate and as the economy developed, real sector which is dominated by the manufacturing sector tended to dominate. Generally during the first half of the 1970s, FDI in each of these sectors were rising. During the early 1980s, FDI in these sectors also tended to rise generally. However, between 1986 and 1992, there was generalized reduction in cumulative FDI which implied that investors withdrew from all sectors of the economy including the famous mining sector where crude oil is dominant. There was a general recovery during the second half of the 1990s with no perceptible pattern in the proportional distribution of sectoral FDI between 1970 and 1999. Gross inflow of foreign direct investment (FDI) were expected to improve in 2010 as first quarter 2010 flows stood at N84.78 billion compared to fourth quarter 2009 inflow of N102.42 billion. All these inflows are toward share equities, banking, telecommunication, manufacturing and oil and gas sectors (CBN 2010).

\subsection{Introduction}

\section{Methodology}

This chapter looks at the research design, model specification, the nature and sources of data as well as the techniques of data analysis.

\subsection{Research Design}

The research employed ex-post facto research design. Ex-post facto research design according to Onwumere (2009) is the type of research involving events that have already taken place. Data already exist as no attempt is made to control or manipulate relevant independent variables. This is suitable for the purpose of our research because it is cost effective.

\subsection{Model Specification}

In order to test for the relevance of the hypothesis regarding the impact of FDI on the Nigerian banking sector, the following model (Regression Model) as in Onwumere (2009:179) which examines the relationship between a dependent variable and one independent variable has been adopted for the respective variables and hypotheses:

$$
\mathrm{Y}=\mathrm{F}(\mathrm{X}) \ldots \ldots \text {. . . . . . . . . . . (1) }
$$

where $\mathrm{Y}$ is the dependent variable which describes banking sector performance indicators such as:

(1) Capital base

(2) Liquidity position

(3) Assets size

$\mathrm{X}$ is the independent variable which represents the FDI (i.e. sectoral FDI inflow or capital imported into the Nigerian banking sector) and $\mathrm{F}$ stands for function.

The above function takes the form of a two-variable linear equation model:

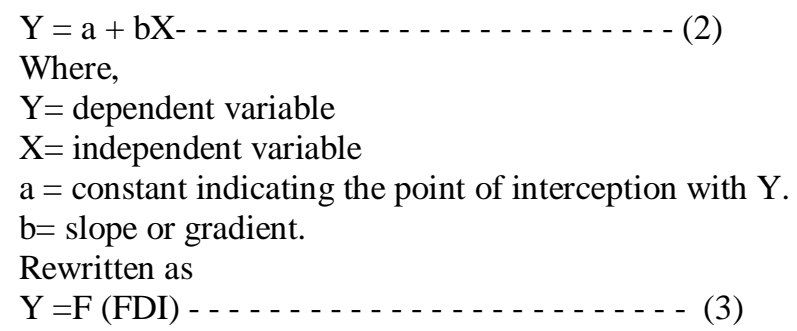

The following alphabets were therefore used to denote their respective variables in the model:

CAP-Capital base

LIQ-Liquidity position

ASST-Assets size

Capital base here constitutes the sum total of equity share capital, reserve fund, reserve for depreciation and non-performing assets as well as loans and advances from Federal and State Government. Liquidity position is evidence of the ability of banks to fund its contractual obligations. It is measured by use of a ratio that gauges bank liquidity. There are many ratios that can be used, but for the purpose of this work we have used the ratio of 
total specified liquid assets to total current liabilities. Assets size simply, is the total assets of banks which are made up of the sum total of foreign assets, unclassified assets, fixed assets etc.

Starting with our first hypothesis which states that there is no positive impact of foreign direct investment on capital base of the Nigerian banking sector, we have-

$\mathrm{CAP}=\mathrm{F}(\mathrm{FDI})$

Our second hypothesis which states that there is no positive impact of foreign direct investment on the liquidity position of the Nigerian banking sector, we have-

LIQ = F(FDI) - . . . . . (5)

For our third hypothesis which states that there is no positive impact of foreign direct investment on total asset size of Nigerian banks, we have-

$$
\text { ASST }=\text { F(FDI) - . . ( }
$$

\subsection{Nature And Sources Of Data}

Data is secondary data. Secondary data uses accounting data of Nigerian deposit money banks from the year 2006-2010. The data for the determination of sectoral FDI inflows into the Nigerian banking sector were obtained from the Central Bank of Nigeria data base for the period 2006-2010 (It must be noted at this point that the CBN started keeping data on FDI capital inflows into Nigerian banks after the 2005 consolidation exercise). Banks met the following conditions in order to be included in the analysis. First they were classified as Nigerian banks in the institutions included within the Nigerian banking sector at $31^{\text {st }}$ Dec. 2009 nationality analysis of the CBN. Second, they were characterized as deposit money banks in CBN data base. Third, they had annual accounting statements (balance sheet and income statement) for at least one year from 2006 to 2010 in the CBN data base.

\subsection{Techniques Of Data Analysis}

The statistical technique employed in testing and analyzing all the hypotheses was regression model. This model is very relevant in testing the hypotheses. The model was employed through the use of the Statistical Package for Social Sciences (SPSS) computer software version 16.0 to ensure accuracy in statistical analysis.

\subsection{Introduction}

\section{Data Presentation And Analysis}

In this chapter, the data obtained through secondary source are presented and analyzed. Data on three out of the five research hypotheses stated in chapter one was also presented. Results derived through the use of regression analysis are presented and interpreted.

\subsection{Data Presentation}

Data for our study are presented in tables and interpreted. Table 4.1 below shows foreign capital importation into the Nigerian deposit money banks (FDI) component and the capital of the Nigerian deposit money banks.

Table 4.1

Table 4.1 below shows the data on foreign capital importation into twenty five Nigerian deposit money banks and their capital from year 2006 to 2010.

\begin{tabular}{|l|l|l|}
\hline Year & $\begin{array}{l}\text { Capital of banks in } \\
\text { Nmillions }\end{array}$ & $\begin{array}{c}\text { Foreign capital injection into banks } \\
\text { (FDI)component in Nmillions }\end{array}$ \\
\hline 2006 & $1,388,856.0$ & $447,166,043.83$ \\
\hline 2007 & $2,225,394.2$ & $9,577,139,517.79$ \\
\hline 2008 & $3,364,693.4$ & $11,171,215,326.99$ \\
\hline 2009 & $4,930,613.0$ & $5,702,888,979.67$ \\
\hline 2010 & $2,217,804.4$ & $5,994,150,018.64$ \\
\hline
\end{tabular}

Source: Central Bank of Nigeria 2010

Table 4.1 above shows data on foreign capital importation into twenty five (25) Nigerian deposit money banks from year 2006 to 2010. The table also shows data on the capital of the twenty five (25) Nigerian deposit money banks for the same period. The data shows that in 2008 FDI rose up to $\$ 11,171,215,326.99$ but dropped down to $\$ 5,994,150,018.64$ in 2010 . This is sequel to the capital flight that occurred as a result of the global economic crisis (credit crunch) in 2008. The capital base of banks rose to $\$ 3,364,693.4$ in 2008, but dropped to only 2,217,804.4 in 2010 . 


\section{Table 4.2}

Table 4.2 below shows the data on foreign capital importation into the Nigerian deposit money banks (FDI) and their liquidity position from year 2006-2010

\begin{tabular}{|l|l|l|}
\hline \multicolumn{1}{|c|}{ Year } & \multicolumn{1}{|c|}{ Liquidity ratio of banks } & $\begin{array}{c}\text { Foreign capital injection into banks } \\
\text { (FDI)component in Amillions }\end{array}$ \\
\hline 2006 & 55.7 & $447,166,043.83$ \\
\hline 2007 & 48.8 & $9,577,139,517.79$ \\
\hline 2008 & 44.3 & $11,171,215,326.99$ \\
\hline 2009 & 30.7 & $5,702,888,879.67$ \\
\hline 2010 & 31.7 & $5,994,150,018.64$ \\
\hline
\end{tabular}

Source: Central Bank of Nigeria 2010.

Table 4.2 above shows the data on foreign capital importation into twenty five (25) Nigerian deposit money banks from the year 2006 to 2010 . The table also shows data on the liquidity position of the Nigerian deposit money banks for the same period. Data shows that liquidity position of these banks was high in 2006 with a 55.7 ratio, implying that after the consolidation exercise in 2005 huge capital inflows were generated by the banking sector. The liquidity position however dropped down to 31.7 in 2010 . This was due to loss of capital through massive flight that occurred in 2008 as a result of the credit crunch.

\section{Table 4.3}

Table 4.3 below shows the data on foreign capital importation into the Nigerian deposit money banks (FDI) and the total assets of the banks from year 2006-2010.

\begin{tabular}{|l|l|l|}
\hline Year & Total assets of banks in Nmillions & $\begin{array}{l}\text { Foreign capital injection into banks } \\
\text { (FDI)component in Nmillions }\end{array}$ \\
\hline 2006 & $7,172,932.1$ & $447,166,043.83$ \\
\hline 2007 & $10,981,693.6$ & $9,577,139,517.79$ \\
\hline 2008 & $15,919,559.8$ & $11,171,215,326.99$ \\
\hline 2009 & $17,522,858.2$ & $5,702,888,879.67$ \\
\hline 2010 & $17,331,559.0$ & $5,994,150,018.64$ \\
\hline
\end{tabular}

Source: Central Bank of Nigeria 2010.

Table 4.3 above shows the data on foreign capital importation for twenty five (25) Nigerian deposit money banks from the year 2006 to 2010 as well as the data on the total assets of the twenty five (25) Nigerian deposit money banks for the same period. The data shows that total assets were valued at $\$ 7,172,932.1$ in 2006 after the consolidation year but rose up to $\$ 15,919,559.8$ in 2008 . In 2010 , total assets value rose up to $\$ 17,331,559.0$ implying that banks invested heavily in assets from the proceeds of the consolidation exercise and the assets value continued to appreciate despite the global economic recession.

\subsection{Test Of Hypotheses And Analysis}

Our hypotheses are tested by first restating them in null and alternative forms as follows:

\subsubsection{Hypothesis One}

$\mathbf{H}_{\mathbf{O}}$ : $\quad$ Foreign direct investment does not have a significant positive impact on the capital base of the Nigerian banking sector.

$\mathbf{H}_{\mathrm{I}}$ : $\quad$ Foreign direct investment does have a significant positive impact on the capital base of the Nigerian banking sector.

The researcher used the Ordinary Least Square (OLS) methodology based on the statistical package for social sciences (SPSS) computer software to test this hypothesis. The OLS otherwise known as the simple regression analysis technique is aimed at establishing the impact of foreign direct investment on the capital base of the Nigerian banking sector.

\section{Presentation of Empirical Results}

Estimated Regression Equation $(\mathrm{ERE})=\quad \mathrm{CAP}=5.10+1.10 \mathrm{FDI}$

Student's - test $\quad\left(\mathrm{t}_{\mathrm{c}}\right) \quad=\quad 1.17$

Standard Error $\quad(\mathrm{S}) \quad=\quad 1.40$

Coefficient of Multiple Determination $\left(\mathrm{R}^{2}\right)=0.20$

\section{Interpretation of the Results}

The equation above $(\mathrm{CAP}=5.10+1.10 \mathrm{FDI})$ shows the estimated regression function. The implication of this function is that an increase in FDI by $1.00 \%$ will only lead to a $1.10 \%$ increase in the capital base of Nigerian banks. The coefficient of multiple determinations $\left(R^{2}\right)$ shows that $20 \%$ of variations in capital (CAP) are explained by changes in FDI. 
The coefficient of FDI is positively insignificant as shown by the student's test $t_{c}$ value of 1.17 . The implication of this is that within the period FDI had an insignificant positive impact on the capital base of the Nigerian banks. The standard error of 1.40 also implies that FDI has a positive but insignificant impact on the capital base of the Nigerian banking sector.

\section{Student's Test $(\mathrm{t}$ - test)}

The researcher calculated the coefficient of FDI using t-test with $\mathrm{n}-\mathrm{k}$ degree of freedom at $5 \%$ level of significance in a two tailed test.
The number of observations in the sample (n)
The number of parameter coefficient $(\mathrm{k})$
The level of significance
Degree of freedom
$(\mathrm{n}-\mathrm{k})$
$(\alpha) \quad=1=5 \%$
4

\section{Decision Rule}

The decision rule is that if the computed $t_{c}$ is greater than the tabular $t$ value we reject the null hypothesis and conclude that changes in the independent variable are significant in influencing changes in the dependent variable, otherwise, we accept the null hypothesis.

Since $t_{c}<t_{t}$ (i.e. $\left.1.17<2.35\right)$ the test statistic falls within the acceptable region of the null hypothesis and we therefore conclude that foreign direct investment (FDI) does not have a significant positive impact on the capital base of the Nigerian banking sector. (See appendix 1)

\subsubsection{Hypothesis Two}

This is restated in null and alternative forms as follows:

$\mathbf{H}_{\mathbf{O}}$ : Foreign direct investment does not have a significant positive impact on the liquidity position of the Nigerian banking sector.

$\mathbf{H}_{\mathbf{I}}$ : Foreign direct investment does have a significant positive impact on the liquidity position of the Nigerian banking sector.

The Ordinary Least Square (OLS) method derived largely from the assumption of the Classical Linear Regression Model (CLRM), the statistical properties of the OLS which are contained in the popular GaussMarkov theorem which sees the least squares estimators as unbiased linear estimators having maximum variance (Onwumere,2009) was employed in testing hypothesis two. This method was employed based on the use of statistical package for social sciences (SPSS) analytical techniques (computer software). This is aimed at determining the impact of foreign direct investment on the liquidity position of the Nigerian banking sector.

\section{Presentation of Empirical Results}

Estimated Regression Equation $(\mathrm{ERE})=\mathrm{LIQ}=45.08-0.13 \mathrm{FDI}$

Student's t-test $\quad\left(\mathrm{t}_{\mathrm{c}}\right)=-0.031$

Standard Error $\quad(\mathrm{S}) \quad=3.34$

Coefficient of Multiple determination $\left(\mathrm{R}^{2}\right)=0.90$

\section{Interpretation of the Results}

The linear function (LIQ=45.08-0.13FDI) above shows the estimated equation that explains the relationship between FDI and liquidity of the Nigerian banks. The coefficient of FDI is not only negative but statistically insignificant (as shown by the $t_{c}$ value of -0.031). The implication is that FDI had a negative insignificant impact on the liquidity position of Nigerian banks. In order words variations in liquidity are not largely explained by changes in FDI. The standard error of 3.34 implies that changes in FDI do not necessarily bring about changes in liquidity position of the banking sector.

\section{Student Test (t-test)}

The student's t-test with n-k degree of freedom of $5 \%$ level of significance in a two tailed test was employed in calculating the coefficient of FDI.

The number of observations in the sample $(\mathrm{n})=5$

The number of parameter coefficient $\quad(\mathrm{k})=1$

The level of significance $\quad(\alpha)=5 \%$

Degree of freedom

$$
(\mathrm{n}-\mathrm{k})=4
$$




\section{Decision Rule}

The decision rule is that if the computed $t_{c}$ is greater than the tabular $t$-value we reject the null hypothesis and conclude that variations in the independent variable are significant in influencing changes in the dependent variable, otherwise, we accept the null hypothesis.

Since $\mathrm{t}_{\mathrm{c}}<\mathrm{t}_{\mathrm{t}}(\mathrm{i}$.e. $-0.031<2.35)$ the test statistic falls within the acceptable region of the null hypothesis and we conclude therefore that foreign direct investment (FDI) does not have a significant positive impact on the liquidity position of the Nigerian banking sector.(See appendix 2)

\subsubsection{Hypothesis Three}

We restate hypothesis three in null and alternative forms as follows:

$\mathbf{H}_{\mathbf{O}}$ : Foreign direct investment does not have a significant positive impact on the total assets of Nigerian banks.

$\mathbf{H}_{\mathbf{I}}$ : Foreign direct investment does have a significant positive impact on the total assets of Nigerian banks.

The Ordinary Least Square (OLS) method was also employed in testing hypothesis three using the statistical package for social sciences (SPSS) computer software. This test was aimed at establishing the impact of foreign direct investment on the total assets size of Nigerian banks.

\section{Presentation of Empirical Results}

Estimated Regression Equation $(\mathrm{ERE})=\mathrm{ASST}=19.06-1.00 \mathrm{FDI}$

Student's t-test $\quad\left(\mathrm{t}_{\mathrm{c}}\right) \quad=-0.27$

Standard Error $\quad(\mathrm{S})=3.66$

Coefficient of multiple determination $\left(\mathrm{R}^{2}\right)=0.40$

\section{Interpretation of the Results}

The linear equation above (ASST=19.06-1.00FDI) shows the estimated function and results of other items expected to be estimated. The function implies that a $1.00 \%$ change in FDI will lead to $-1.00 \%$ changes in assets. The coefficient of multiple determination shows that $40 \%$ of variations in assets (ASST) are explained by changes in FDI. The coefficient of FDI is not only negative but statistically insignificant (as shown by the $t_{c}$ value of -0.27). The implication of this is that within the period, FDI had a negative insignificant impact on total assets. In order words variations in assets are not necessarily explained by changes in FDI.

\section{Student Test (t-test)}

The coefficient of FDI was calculated using t-test with $n-k$ degree of freedom at $5 \%$ level of significance in a two -tailed test.

The number of observations in the sample $(n)=5$

The number of parameter coefficient $\quad(\mathrm{k})=1$

The level of significance $\quad(\alpha)=5 \%$

Degree of freedom $\quad(\mathrm{n}-\mathrm{k})=4$

\section{Decision Rule}

The decision rule in using t-test is that if the computed $t_{c}$ is greater than the tabular $t$ value we reject the null hypothesis and conclude that changes in the independent variable are significant in influencing changes in the dependent variable, otherwise, we accept the null hypothesis.

Since $t_{c}<t_{t}(i . e-0.27<2.35)$ the test statistic falls within the acceptable region of the null hypothesis and we conclude that foreign direct investment (FDI) does not have a significant positive impact on the total asset size of Nigerian banks (See appendix 3

\subsection{Introduction}

\section{Summary Of Findings, Conclusion And Recommendations}

This chapter summarizes the various research results which emerged from the study. The results are aligned with the respective objectives and hypotheses set out in chapter one of the dissertation. Conclusions are drawn and necessary recommendations made based on the research findings.

\subsection{Summary Of Findings}

The major thrust of this study was to ascertain the level of impact; foreign direct investment has on the Nigerian banking sector in the wake of the unprecedented capital flight that occurred during the recent global economic meltdown (The credit crunch). The research work basically sought to determine the amount and impact of cumulative FDI inflows that came into the Nigerian banking sector from the year 2006 to 2010 and to 
ascertain the extent to which foreign direct investment impacts on the liquidity position and total assets of Nigerian banks within the same period.

On the whole, three (3) null hypotheses and research questions were raised, tested and verified. This was done using the simple regression analysis. The statistical package for social sciences (SPSS) computer software version 16.0 was also used. Results were obtained using both the student's t-test and the standard error tools of analysis.

Corresponding with the three (3) objectives of the study earlier set out in chapter one, the following major findings were made:-

(1) Foreign direct investment capital inflows that came into the Nigerian money deposit banks were about \#32.9 billion for year 2006 to 2010 . This represents a $44 \%$ positive but insignificant percentage of the total capital base of the entire banking sector for this period. The regression coefficient of FDI was positive but insignificant (as shown by $t_{c}$ value of 1.17) implying that FDI has an insignificant positive impact on the capital base of the Nigerian banking sector.

(2) The liquidity position of the Nigerian banking sector from year 2006 to 2010 was high but experienced a declining trend. Foreign direct investment for the period was found to have a negative insignificant impact on the liquidity position of the Nigerian banking sector (as seen in t-test value $t_{c}=-0.031$ ). The implication of this is that changes in liquidity of the banking sector do not necessarily depend on changes in foreign direct investment.

(3) Lastly it was found out that the total asset size of the Nigerian banks rose steadily in value from year 2006 to 2010 ranging from $\$ 7,172,932.1$ in 2006 to $\$ 17,522,858.2$ in 2009 . Foreign direct investment however, had a negative insignificant impact on the total assets (as shown by the coefficient of FDI $t_{c}=-0.2$

\subsection{Conclusion}

Based on the findings of this research work enumerated in section 5.2 above which states that:

$>$ Foreign direct investment has an insignificant positive impact on the capital base of the Nigerian banking sector.

$>$ Foreign direct investment has a negative insignificant impact on the liquidity position of the Nigerian banking sector.

> Foreign direct investment has an insignificant negative impact on the total asset size of the Nigerian banking sector,

The research work concludes therefore that foreign direct investment (FDI) does not have a significant positive impact on the Nigerian banking sector. In order words, the sustainability and growth (development) of the Nigerian banking industry is not necessarily a function of foreign direct capital injection. Put in another way, growth in the banking sector is not necessarily made possible by the increase in the flow of foreign capital. The Nigerian banking sector perhaps, depends largely on other sources of capital rather than the foreign capital for its growth and sustainability. This conclusion is consistent with the findings of other studies conducted in the past with respect to the impact of FDI on sectoral composition of the Nigerian economy in particular, and other developing economies in general.

\subsection{Recommendations}

Based on the issues raised above and in line with the findings of this work, the following recommendations are therefore necessary:

(1) That the Nigerian Government should take more seriously the responsibility of creating an enabling environment for effective, value-adding foreign direct investment, particularly in the banking sector, without losing the prerogative of sovereignty. What this mean is that Government should step up efforts in attracting foreign direct investment into the sector by ensuring that investor confidence is protected. This can be done through:

- Providing visionary government that puts the interest of the average Nigerian first and not those of political parties, politicians or a few already wealthy rent seekers.

- Establishing and supporting a culture of business ethics and integrity through effective regulation. Foreign direct investors and their investments should be subjected to more rigorous and effective regulation in order to avoid cases of capital flight especially during times of financial crisis. Corruption poses a fundamental risk to Nigeria and its governance. This has kept many foreign firms from investing in the country. But with effective regulatory framework put in place, corruption and other related issues will be addressed.

* Ensuring policy consistency. This is essential if we are to obtain long-term benefits from foreign direct investment; foreign investment policies that change at the whim or caprice of every newly elected government will not do the nation any good. This is because they generate needles disputes that weaken investor confidence and raise questions about the sanctity of contracts - one of the basic tenets of the rule of law. 
(2) Foreign direct investment capital inflows brought into the Nigerian banking sector and the economy generally must be sustainable. For foreign direct investment to be sustainable, it must create wealth not just for foreign investors, but also for Nigerians. The time is long past when foreign investment in Africa was all about extracting wealth while leaving Africans poorer than they were before the investors arrived. It is recommended that government should come out with policies that encourage wealth creation and generation by Nigerians from within the economy (squeezing wealth from foreign investments by Nigerians) so as to avoid overdependence on foreign capital. Today, foreign investment must create economic and social value for the host country, even as foreign investors certainly have a right to run viable businesses. But as we have seen in the global financial crisis, there is a difference between viable business and the unchecked greed that created much of the mess the world is in today.

(3) The Government should look at foreign direct investment now from a deeper perspective than just that of the quality of dollars or how many companies that comes into Nigeria as foreign investment. We must look at the quality and structure of foreign investment and we must address the question of whether FDI automatically catalyses development. It is widely believed that FDI is essential for development. It certainly can play a key role in development provided certain conditions are met, as has been the case in the Newly Industrialized Countries (NICs) of Asia. But there is also significant empirical evidence that FDI complements, but does not substitute local factors that are essential for development. In any case, the present global economic crisis has led to a downturn in FDI flows worldwide including Nigeria. The ways in which foreign investment can contribute concretely to development include the diffusion of technology into the host country's economic system, strategically targeted foreign investment in the real economy (power, manufacturing), export-oriented industries, service industries and the use of local suppliers, rather than a lopsided focus on extractive industries.

\section{List Of Appendixes}

Statistical Package For Social Sciences (Spss) Results

\section{Regression}

\section{APPENDIX 1}

\begin{tabular}{|c|c|c|c|}
\hline \multicolumn{4}{|c|}{ Variables Entered/Removed ${ }^{\text {b }}$} \\
\hline Model & Variables Entered & $\begin{array}{l}\text { Variables } \\
\text { Removed }\end{array}$ & Method \\
\hline 1 & $\mathrm{FDI}^{\mathrm{a}}$ & 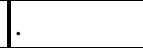 & Enter \\
\hline
\end{tabular}

Model Summary
\begin{tabular}{|l|l|l|l|l|}
\hline Model & R & R Square & Adjusted R Square & $\begin{array}{l}\text { Std. Error of the } \\
\text { Estimate }\end{array}$ \\
\hline 1 & $.559^{\mathrm{a}}$ & .202 & .083 & $1.53967 \mathrm{E} 6$ \\
\hline
\end{tabular}

a. Predictors: (Constant), FDI

ANOVA $^{\mathbf{b}}$
\begin{tabular}{|ll|l|l|l|l|l|}
\hline Model & & Sum of Squares & Df & Mean Square & F & Sig. \\
\hline 1 & Regression & $3.229 \mathrm{E} 12$ & 1 & $3.229 \mathrm{E} 12$ & 1.362 & $.328^{\mathrm{a}}$ \\
& Residual & $7.112 \mathrm{E} 12$ & 3 & $2.371 \mathrm{E} 12$ & & \\
& Total & $1.034 \mathrm{E} 13$ & 4 & & & \\
\hline
\end{tabular}

a. Predictors: (Constant), FDI

b. Dependent Variable: CAPITAL

Coefficients $^{\mathrm{a}}$

\begin{tabular}{|c|c|c|c|c|c|c|}
\hline \multirow{2}{*}{\multicolumn{2}{|c|}{ Model }} & \multicolumn{2}{|c|}{ Unstandardized Coefficients } & \multirow{2}{*}{\begin{tabular}{|l} 
Standardized \\
Coefficients \\
Beta
\end{tabular}} & \multirow[b]{2}{*}{$\mathrm{T}$} & \multirow[b]{2}{*}{ Sig. } \\
\hline & & B & Std. Error & & & \\
\hline \multirow[t]{2}{*}{1} & (Constant) & 5.10 & $1.070 \mathrm{E} 6$ & & 1.510 & .228 \\
\hline & FDI & 1.10 & 1.400 & .559 & 1.167 & .328 \\
\hline
\end{tabular}

a. Dependent Variable: CAPITAL 


\section{Regression}

\section{APPENDIX 2}

Variables Entered/Removed $^{\text {b }}$

\begin{tabular}{|l|l|l|l|}
\hline Model & Variables Entered & Variables Removed & Method \\
\hline 1 & FDI $^{\mathrm{a}}$ &. & Enter \\
\hline
\end{tabular}

a. All requested variables entered.

b. Dependent Variable: LIQUIDITY

Model Summary

\begin{tabular}{|l|l|l|l|l|}
\hline Model & $\mathrm{R}$ & R Square & Adjusted R Square & $\begin{array}{l}\text { Std. Error of the } \\
\text { Estimate }\end{array}$ \\
\hline 1 & $.380^{\mathrm{a}}$ & 0.90 & -.141 & 10.08255 \\
\hline
\end{tabular}

a. Predictors: (Constant), FDI

ANOVA $^{b}$

\begin{tabular}{|ll|l|l|l|l|l|}
\hline Model & & Sum of Squares & Df & Mean Square & F & Sig. \\
\hline 1 & Regression & 51.559 & 1 & 51.559 & .507 & $.528^{\mathrm{a}}$ \\
& Residual & 304.973 & 3 & 101.658 & & \\
& Total & 356.532 & 4 & & & \\
\hline
\end{tabular}

a. Predictors: (Constant), FDI

b. Dependent Variable: LIQUIDITY

Coefficients $^{\mathrm{a}}$

\begin{tabular}{|c|c|c|c|c|c|c|}
\hline \multirow{2}{*}{\multicolumn{2}{|c|}{ Model }} & \multicolumn{2}{|c|}{ Unstandardized Coefficients } & \multirow{2}{*}{\begin{tabular}{|l}
$\begin{array}{l}\text { Standardized } \\
\text { Coefficients }\end{array}$ \\
Beta
\end{tabular}} & \multirow[b]{2}{*}{$\mathrm{T}$} & \multirow[b]{2}{*}{ Sig. } \\
\hline & & B & Std. Error & & & \\
\hline \multirow[t]{2}{*}{1} & (Constant) & 45.080 & 7.008 & & 7.101 & .006 \\
\hline & FDI & $-0.132 \mathrm{E}-10$ & 3.34 & .380 & -0.031 & .528 \\
\hline
\end{tabular}

a. Dependent Variable: LIQUIDITY

\section{Regression}

\section{APPENDIX 3}

\begin{tabular}{|l|l|l|l|l|l|l|}
\hline \multicolumn{2}{|c|}{ ANOVA $^{\mathbf{b}}$} & Sum of Squares & Df & Mean Square & F & Sig. \\
\hline 1 & Regression & $6.747 \mathrm{E} 13$ & 1 & $6.747 \mathrm{E} 13$ & 3.632 & $.153^{\mathrm{a}}$ \\
& Residual & $5.573 \mathrm{E} 13$ & 3 & $1.858 \mathrm{E} 13$ & & \\
& Total & $1.232 \mathrm{E} 14$ & 4 & & & \\
\hline
\end{tabular}

a. Predictors: (Constant), FDI

b. Dependent Variable: ASSETS

Variables Entered/Removed $^{\text {b }}$

\begin{tabular}{|l|l|l|l|}
\hline Model & Variables Entered & Variables Removed & Method \\
\hline 1 & FDI $^{\mathrm{a}}$ &. & Enter \\
\hline
\end{tabular}

a. All requested variables entered.

b. Dependent Variable: ASSETS 


Model Summary
\begin{tabular}{|l|l|l|l|l|}
\hline Model & R & R Square & Adjusted R Square & $\begin{array}{l}\text { Std. Error of the } \\
\text { Estimate }\end{array}$ \\
\hline 1 & $.740^{\mathrm{a}}$ & 0.40 & .397 & $4.31001 \mathrm{E} 6$ \\
\hline
\end{tabular}

a. Predictors: (Constant), FDI

\section{Coefficients $^{\mathrm{a}}$}

\begin{tabular}{|c|c|c|c|c|c|c|}
\hline \multirow{2}{*}{\multicolumn{2}{|c|}{ Model }} & \multicolumn{2}{|c|}{ Unstandardized Coefficients } & \multirow{2}{*}{\begin{tabular}{|l} 
Standardized \\
Coefficients \\
Beta
\end{tabular}} & \multirow[b]{2}{*}{$\mathrm{T}$} & \multirow[b]{2}{*}{ Sig. } \\
\hline & & B & Std. Error & & & \\
\hline 1 & (Constant) & 19.06 & 2.996E6 & & 2.287 & .106 \\
\hline & FDI & -1.001 & 3.66 & .740 & -0.27 & .153 \\
\hline
\end{tabular}

a. Dependent Variable: ASSETS

\section{Bibliography}

[1] Aremu,J.A.(2003), An Overview of Foreign Private Investment in Nigeria: inProceedings of the Twelveth Annual Conference of the CBN Regional Research Unit. Kaduna

[2] Achen, C.H. (1982), Interpreting and Using Regression, California: Sage Publication.

[3] British Bankers Association, 2004.The Banking Sector's Contribution to theEconomy, Available at http://www.bba.org.uk

[4] CBN (2003), Foreign Private Investment in Nigeria: Proceedings of theTwelveth Annual Conference of the Regional Research Units, Kaduna.

[5] CBN (2010) Statistical Bulletin, http://www.cenbank.org/out/2011/publications/statistics/2010/index.htm

[6] CBN (2009), Institutions Included within the Nigerian Banking Sector's Nationality Analysis, 10(1),pp 5-8.

[7] Caves,R.E., 1971. International Corporations: Economics of Foreign Investment, Economical, The Industrial 38(4),pp1-27.

[8] Caves, R.E., 1974. Multinational Firms: Competition and Productivity in Host Country Markets, Economical, $41(3)$,pp176- 193.

[9] Ekpo A. N (1997), "Foreign Direct Investment in Nigeria: Evidence from Time Series Data" CBN Economic and Financial Review, Vol. $35 \quad$ No. 1

[10] Emory, C.W. (1976), Business Research Methods, Homewood Illinois:Richard D.Irwin Inc.Eriksson,G. (1990), Development of the African Economy by Foreign Direct Investment with SpecialReference to Nigeria, Washington DC: World Bank

[11] Eriksson,G. (1990), Development of the African Economy by Foreign Direct Investment with Special Reference to Nigeria, Washington DC: World Bank

[12] Glass, A.J. and K.Saggi, 1998. International Technology Transfer and the Technology Gap, Journal of Development Economics, 55(7), pp369-398

[13] Gujarati, D. N. (2004), Basic Econometrics, New Delhi: Tata McGraw - Hill.

[14] Goldberger,A.S.(1991),A Course in Econometrics, Massachussets:Harvard University Press.

[15] Hu, T. (1977), Econometrics: An Introductory Analysis, Baltimore:University Park Press.

[16] Hymer, S.H. (1960), The International Operations of National Firms:A Study of Direct Foreign Investment, Cambridge:MIT Press .

[17] Koutsoyiannis, A. (1972), The Theory of Econometrics,London and Basingtoke: Macmilla Press Ltd.

[18] Lall, S. (1999), The Technological Response to Import Liberalization in Sub- Saharan Africa, London:Macmillan.

[19] Lensink, R and Morrissey, O. (2001), Foreign Direct Investment: Flows, Volatility and Growth in Developing Countries, University of Nothingham,Mimeo.

[20] Lipsey,R.(2000), Interpreting Developed Countries FDI,NBER Working Paper No.7810.

[21] Luck, D.J. and R.S. Rubin (1989), Marketing Research, New Delhi: Prentice Hall of India Private Ltd

[22] Merrington M., (1941), Table of Percentage Points of the t-Distribution,Biometrika 32(1941)

[23] Moghalu K. (2009), "Strategic Approach to Foreign Investment in Nigeria"in Business and Investment Forum for Nigerian Governors. Zurich.

[24] Moosa, A.I. (2002), Foreign Direct Investment: Theory, Evidence and Practice, New York: Palgrave

[25] Onwumere, J.U.J (2009), Business and Economic Research Methods, Enugu: Vougasen Limited.

[26] Onimode, B.(1983), Multinational Corporations in Nigeria,Ibadan: Skyraden.

[27] Oyeranti,O.A (2003), Foreign Private Investment: Conceptual and Theoretical Issues, Ibadan: Department of Economics.

[28] Odedokun, Matthew (2003), "A Holistic Perception of Foreign Financing of Development Countries' Private Sectors: Analysis andDescription of Structure and Trends",WIDER Discussion Paper No.2003/01.

[29] Przewoski, A.and F. Limongi 1993. Political Regimes and Economic VGrowth, Journal of Economic Perspectives, 7(2), pp 51-69.

[30] Pierre Coupet (2009) Global Economic Meltdown: Time for Startups to Explore New Monetization Strategy, January 9. Retrieved 2009-12-05.

[31] Romer, Paul, 1993. Ideal Gaps and Object Gaps in Economic Development, Journal of Monetary Economics, 32(1),pp 543573.

[32] Riddel, R. and L. Cockcraft (1991) "Symposium: Foreign Direct Investment: in I.Hussain and J. Underwood” (1990), African External finance, Washington DC: World Bank.

[33] Sadiq,T.Alli and Bolbol,A.Ali (2001), "Capital Flows,FDI,and Technology Spillovers: Evidence from Arab Countries" World Development, Vol.29, no.12,pp.2111-2125.

[34] Salif, A., 2008. Credit Crunch Hits Economy. Board Street Nigeria's Authoritative Business Weekly, 43(6), pp 7-12

[35] Saltz, I. (1973), The Negetive Correlation Between FDI and Economic Growth in the Third World: The Theory and Evidence, Rivista Internationale di Scienze Economiche Economerciali.Vol. 30,pp 617-633.

[36] Summers, Lawrence (2000), International Financial Crises: Causes,Prevention and Cures, American Economic Review,90(5), pp $1-16$. 
[37] Sadiq,T.Alli and Bolbol,A.Ali (2001), “Capital Flows,FDI, and Technology Development, Vol.29, no.12,pp.2111-2125.

[38] Summers, Lawrence (2000), International Financial Crises: Causes, Prevention $1-16$.

[39] Todaro,M.P. (1994), Economic Development, London and Newyork: Longman.

[40] Thrilwall, A.P. (1994), Growth and Development, London:Macmillan.

[41] Uche, C.U and Osho, B. 1997. Rethinking Deposit Insurance inNigeria. Journal of International Banking Law, 6,pp242-243

[42] Uche, C.U, 2005. Ethics in Nigerian Banking, Journal of Money Laundering

[43] Uche H.O. (2004), New Approach to International Finance,Lagos:

CIBN press ltd.
Spillovers: Evidence from Arab Countries" World and Cures, American Economic Review,90(5),pp Control, 1(3), pp66-67 